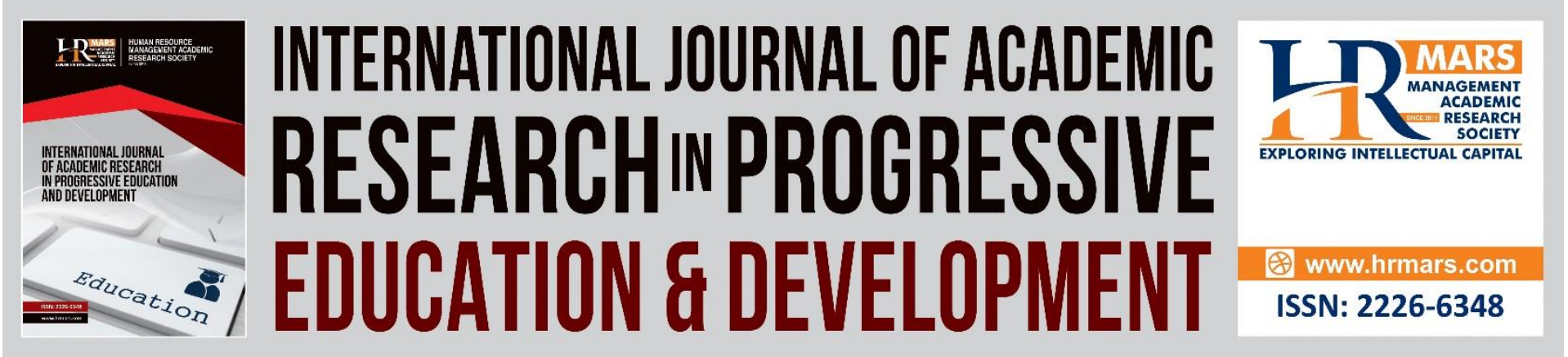

\title{
Entertainment Media Channels Usage Patterns During the Movement Control Order (MCO) Period in Malaysia
}

Siti Nor Fazira Jono, Mohd Syuhaidi Abu Bakar

To Link this Article: http://dx.doi.org/10.6007/IJARPED/v10-i3/11102

DOI:10.6007/IJARPED/v10-i3/11102

Received: 05 June 2021, Revised: 11 July 2021, Accepted: 30 July 2021

Published Online: 21 August 2021

In-Text Citation: (Jono \& Bakar, 2021)

To Cite this Article: Jono, S. N. F., \& Bakar, M. S. A. (2021). Entertainment Media Channels Usage Patterns During the Movement Control Order (MCO) Period in Malaysia. International Journal of Academic Research in Progressive Education and Development, 10(3), 650-659.

Copyright: (C) 2021 The Author(s)

Published by Human Resource Management Academic Research Society (www.hrmars.com)

This article is published under the Creative Commons Attribution (CC BY 4.0) license. Anyone may reproduce, distribute, translate and create derivative works of this article (for both commercial and non-commercial purposes), subject to full attribution to the original publication and authors. The full terms of this license may be seen

at: http://creativecommons.org/licences/by/4.0/legalcode

\section{Vol. 10(3) 2021, Pg. 650 - 659}

Full Terms \& Conditions of access and use can be found at http://hrmars.com/index.php/pages/detail/publication-ethics 


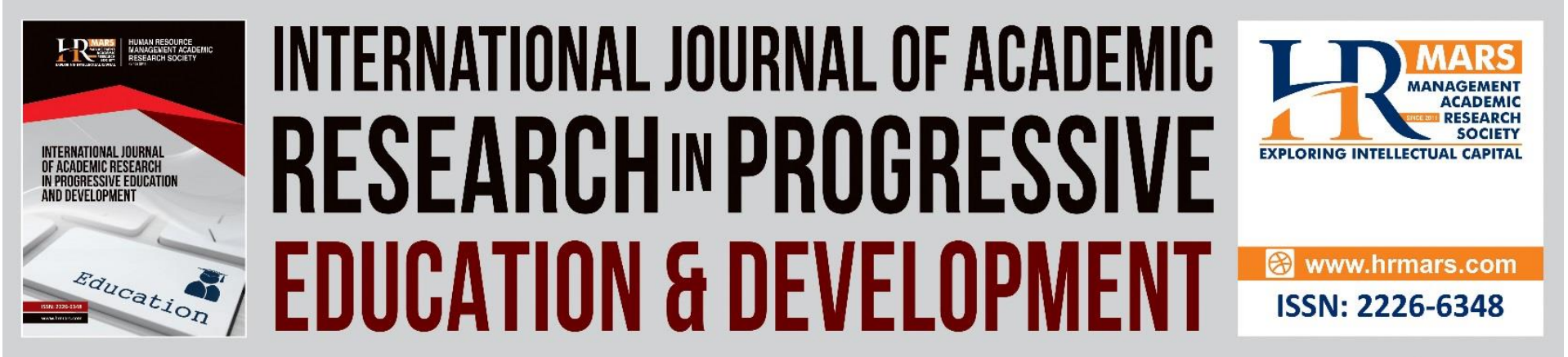

\title{
Entertainment Media Channels Usage Patterns During the Movement Control Order (MCO) Period in Malaysia
}

\author{
Siti Nor Fazira Jono \\ Faculty of Film, Theatre, and Animation (FiTA), Universiti Teknologi MARA (UiTM), Puncak \\ Perdana Campus, Malaysia \\ Email: 2019506865@isiswa.uitm.edu.my \\ Mohd Syuhaidi Abu Bakar \\ Faculty of Film, Theatre, and Animation (FiTA), Universiti Teknologi MARA (UiTM), Puncak \\ Perdana Campus, Malaysia \\ Email: syuhaidi@uitm.edu.my
}

\begin{abstract}
With the increase of the new COVID-19 cases, the Movement Control Order (MCO) was introduced in Malaysia on March 18, 2020. It requires the closure of all businesses except those providing essential services and goods. The daily life of Malaysians changed tremendously due to the COVID-19 pandemic, and all Malaysians had to adapt to the new normal. Thus, Malaysians turn to media channels to acquire authentic news and information. The entertainment media channel also changes its role in providing news and stories to Malaysians. This study focused on the use of entertainment media channels during the period of the MCO in Malaysia. A total of 10 informants were interviewed using a qualitative approach. Data were transcribed verbatim. The results of this study found that during MCO, Malaysians uses entertainment media channels as the new normal, as a means of entertainment, to read the news online, play online games and generate income on digital platform and watch free TV channels. In conclusion, media entertainment channels have contributed to reducing the stress faced by Malaysians and to provide authentic information throughout the MCO period.
\end{abstract}

Keywords: Entertainment Media Channels, Movement Control Order, Malaysia, COVID-19

\section{Introduction}

On 18 March 2020, the Malaysian government implemented the Movement Control Order (MCO) which required all Malaysians to comply with the new law enforcement or the new normal as announced by the former Prime Minister of Malaysia, Tan Sri Muhyiddin Yassin. Daily activities, such as evening leisure activities, trips to shopping centres and cinemas, 
school and university activities, as well as food and drink operations, had to be temporarily closed.

According to Jaafar (2020), the outbreak of COVID-19 has led to an increase in the unemployment rate and the lack of income. According to Hayin (2020), life in Malaysia has changed drastically and it is difficult to adapt to the new environment. All daily activities often performed outside the home, such as work or learning, were to be performed at home. It certainly caused emotional stress to people.

In line with the advances in information and communication technologies (ICT), exposure to unauthorized news and information on social media such as blogs, Twitter, Facebook, Instagram, Telegram and WhatsApp has increased public impact and pressure (Hayin, 2020). Thus, entertainment media channels such as radio and television stations, as well as official social media accounts, have become a space for Malaysians to verify news from time to time so that they are not fooled by fake news on social media platforms like Facebook, WhatsApp and others.

The entertainment media channel plays an important role in delivering the right news and information to people. According to Sallehuddin (2020), Media Prima Berhad (Media Prima) has been updating the latest information on the outbreak of COVID-19 through its TV channels. This is also an important role in ensuring that Malaysians do not missed the latest information issued by the government, especially in terms of SOP and health care guidelines developed by the Ministry of Health ( $\mathrm{MOH}$ ) and the National Security Council (MKN).

In fact, today's talk shows such as Malaysia Hari Ini (MHI) and Wanita Hari Ini (WHI) have also helped to broadcast and update the latest news of the COVID-19 outbreak in the country. In addition, the entertainment media have helped to reduce anxiety among people by creating informative messages. According to Bernama (2020), in line with the MCO enforcement, the Ministry of Communications and Multimedia Malaysia (KKMM) has brought new initiatives by providing digital content to homes such as \#MuzikDirumah. It features wellknown celebrities such as Datuk Jamal Abdillah, Hujan, Ayda Jebat and several other artists to encourage Malaysians to stay home.

In addition, this online entertainment initiatives also influences the growth of the economy by generating productive artists and crews, which fosters the spirit of unity to cope with the COVID-19 pandemic. Undoubtedly, the spread of COVID-19 had indeed had an impact on the country's economy. The spread of COVID-19 throughout the country has affected the business sector, the oil and palm sector, the manufacturing industry, the arts industry and large companies with high overall costs, and as a result, affected the country's economy (Bernama, 2020)

In addition, the unemployment rate in the country has increased since the introduction of MCO because many companies have been affected and have closed down their operations. However, the development of mass media and technology at the present time could help people to be creative in the generation of daily income. For example, entertainment media such as YouTube, Instagram or Facebook can generate revenue through the sale of online products, paid review or act as a sales agent for product companies. In the current situation, entertainment media play an important role in attracting attention or offering entertainment to Malaysians. Since the implementation of the MCO, several multimedia entertainment channels have also helped alleviate Malaysians' concerns about the COVID-19 pandemic by providing free channels to Malaysians such as iFlix VIP, Astro GO 
channels and also by getting support from a free internet access from Maxis and Digi (Bernama, 2020).

According to Mohd (2020), iflix announced on its site that they will show free movies such as Daulat, Ghost Writer and Pengabdi Setan exclusively because during the MCO period, the community was banned from going to the cinema, as well as to leave the house for entertainment experience. Therefore, IFlix has provided a free platform to watch hundreds of free movies and TV series in the comfort of their own home with family members. At the same time, Ellias (2020) said the government introduced the Nyanyi Dari Rumah (NDR) initatives. The aim of this NDR plan is to ensure that the art industry is not seriously affected within the MCO period. The program undertaken by Radio Televisyen Malaysia (RTM) is to attract Malaysians to perform at home.

According to Sualman (2019), Malaysia is ranked among the fifth in the world and one of the best in South-East Asia in the use of social mobile networks. In addition, Hootsuite and We Are Social in their latest 2019 digital report mentioned the use of the Internet in Malaysia reaches $80 \%$. Malaysians spent an average of eight hours a day online. This is due to the development of digital media at this time and a wide range of information that can be obtained from various platforms with only the Internet. Thus, this study aims to explore various entertainment media platforms used by Malaysians during the MCO period.

\section{Literature Review}

The COVID-19 pandemic has affected Malaysians, especially the country's economy and everyday life of the people. This caused anxiety among Malaysians when it was announced by the former Prime Minister of Malaysia that within the MCO period, people cannot leave the house to conduct daily activities. Thus, The KKMM plays an important role in monitoring the spread of false news on social media. Social media accounts including the official media space such as the @kkmm_gov or @KKMPutrajaya on Twitter have always provided authentic and accurate information. In addition, television also reports new cases and accurate information to be shared with Malaysians.

\section{Entertainment Media Channels and Income Generation}

During the MCO, daily affairs such as working and small businesses operations are temporarily closed. Many Malaysians are depressed due to limited savings and lack of income. According to Lajis (2020), YouTube sensation 'Sugu Pavitra' received public attention by simply uploading cooking videos on her YouTube channel. She earned 142,000 subscribers on YouTube. As a result of her recipe-sharing videos, she has generated income at home through YouTube.

Tee (2020) said the worries and concerns were felt by all Malaysians because the MCO stopped daily outdoor activities to prevent the spread of the COVID-19 virus. However, online sales have not ceased in Malaysia. Entertainment media like YouTube, Instagram, Facebook and others are used by business owners to promote their products to the public.

As a result, restaurant operators or product vendors may continue to operate and gain sales during the MCO period. There are many food delivery services, such as FoodPanda and GrabFood. Business owners only have to register their business in food delivery service applications and can continue to function as usual. For small business operators, they can also use their own personal service and provide cash-on-delivery (COD) service in nearby areas by adhering to the government's standard operating procedure (SOP) (Tee, 2020). The need to 
earn income during the MCO period has taught many Malaysians how to use social media and entertainment platforms well.

\section{Entertainment Media Channels and Sharing Knowledge \& e-Learning}

Hussain (2020) said, the MCO period has been stressful for all Malaysians, especially when citizens have been forced not to do any outdoor activity. However, some take advantage of family time by using social media. YouTube is a social media that can be easily accessible to watch home decorating lessons or find exciting cooking recipes. Thus, new knowledge can be acquired and learned via YouTube. In addition, health-care activities can be carried out at home with the family by simply following health-related channels that could eliminate stress.

According to Astro Awani (2020), the Ministry of Education conducted learning sessions through television channels during the MCO period. Astro has taken proactive steps by introducing the "Kuiz Pantas TTV". The purpose of the program is to ensure that students still have the opportunity to learn at home and that learning does not stop during the MCO period. In addition, this slot is a free channel for all Malaysians. The answers will be checked by a professional teacher who is appointed by Astro's management. It is clear that with a network of educational channels such as Astro's TUTOR TV, students will continue to follow the syllabus while learning at home and preparing for the exam.

According to Hassan (2020), Malaysia has recorded the second highest number of Internet users in the world during the first three days of implementation of the MCO. The results show that Malaysia has recorded a 9 per cent increase in Internet use compared with the previous month of February 2020. It was anticipated beforehand because all issues related to work and learning sessions had to be carried out at home, that is. Many were completely dependent on the Internet.

The telecommunications industry has offered special packages for all users, including efforts to improve the telecommunications network. Therefore, KKMM stated that the special package free internet that offered to all Malaysians was worth RM600 million. This also includes all post-paid and prepaid customers from Celcom, Digi, Maxis and $U$ Mobile who receive 1 GB of high-speed Internet for each user from 8 a.m. to 6 p.m (Nana, 2020).

Astro has offered free access to 22 channels, including movie channels for its customers throughout the MCO period. Astro also offers Astro Go platforms, including channels such as HBO, FOX Movies, Celestial Movies, tvN Movies, BollyOne and many more. According to Astro, this initiative aims to reduce worries and concerns about the spread of the COVID-19 pandemic (Huda, 2020).

In addition, channel 146 of Astro collaborated with KKMM on the introduction of a television educational slot during the MCO period, which came into effect on July 6, 2020. Students who do not have a mobile phone or Internet can continue learning through the existing TV network (FMT Reporters, 2020). According to Mohd (2020), iFlix channel offers a variety of free movies of different genres so the public can watch.

\section{Methodology}

This is a qualitative study. Guest, Bunce and Johnson (2006) found that saturation occurred within the first twelve interviews. However they also found that basic elements for metathemes were present as early as six interviews. In this paper, a total of 10 Malaysian informants from different occupational levels and ages were interviewed. They all use 
DEVELOPMENT

Vol. 10, No. 3, 2021, E-ISSN: 2226-6348 @ 2021 HRMARS

different means of media entertainment channels during the period of the MCO. Data were transcribed verbatim.

\section{Findings and Discussion}

\section{Entertainment Media Channels as the New Normal}

The development of Internet, WEB 2.0 and communication technologies has allowed users to interact or socialise online using only the Internet network. The existence of the Internet at present has enabled Internet users to export, share and disseminate information through social media sites such as Twitter, YouTube, Facebook, Instagram and a variety of new existing platforms (Salleh \& Ilham, 2017). In addition to this, technology is now dedicated to the introduction of new applications with incredible varieties. You can get information or news on the Internet, as well as on social media.

During the MCO period, schools and universities are temporarily closed to prevent the spread of the COVID-19. However, regular assignments and lessons are normally conducted using online learning methods. This also implies the cooperation of parents in the supervision of their children in order to carry out the tasks assigned by teachers and lecturers. According to Informant 1, as a housewife, she is responsible for monitoring her children's homework at home.

The informant also stated that other tasks have also been performed using social media platforms such as WhatsApp, YouTube and Facebook. WhatsApp usage is for online contact, shared videos and photos to friends. While Facebook have been used to watch videos and images uploaded by friends in the virtual world. The informant added that, she now master Google Search. According to Informant 2, a lecturer is still responsible for giving tasks or tasks to students. Informant 5, who is a student at Universiti Kebangsaan Malaysia (UKM) said, during the MCO period, all assignments were assigned via WhatsApp or online meeting using the Google Meet application.

\section{TikTok as A Means of Entertainment}

According to Informant 4, the development of the Internet attracts public attention. This is because the Internet is not just a network for finding information or visiting an online platform, it also gives people space to learn something new.

This was also supported by informant 9, who said while working from home during this $\mathrm{MCO}$, she found TikTok as a place to spend time. According to the informant, the problem she faced while working at home was the lack of inspiration. After learning about the TikTok app, she was able to learn new things. It was also agreed by Informant 6.

The Managing Director of Mydin Mohamed Holdings Bhd, Datuk Ameer Ali Mydin has taken steps to attract public attention using the TikTok app, uploading a video in conjunction with Father's Day celebration and has since gained positive views by Malaysians (Muhammad, 2020).

Parzi and Ruzki (2020) said, during the MCO period, Malaysians are concerned about their earnings and financial problems. This was supported by Informant 8 as she was one of the employees who had to be dismissed by the employer at the beginning of the MCO period. 
This resulted in the difficulty and loss of the informant's income. According to Informant 8, however, she is looking for ideas in the entertainment media channels to regain her income.

\section{Reachability of Online News}

Some people, especially the elderly, are unaware of the existence of online newspapers as a free digital medium and they are accessible to society. Since the COVID-19, Informant 7 only read news on his mobile phone. It's easy and time-saving.

In addition, Informant 1 and 9 also had access to the latest news available on the Web during the MCO period. According to Informant 9, she simply Google or follow online news on Twitter or Facebook.

In addition, Informant 5 also supports the acceptance of Facebook as a media platform because he only uses Facebook as a social media to get information during the MCO period.

\section{Generating Income on Digital Platform}

Tee (2020) said that uncertain global economies have motivated the community to start taking creative steps to generate revenue through various social media platforms such as Facebook, Instagram, YouTube, etc. The impact of the COVID-19 pandemic is considered to have an impact on the global economy. Malaysians must therefore be smart and creative to ensure that existing platforms can help them maintain their incomes.

According to Informant 1 , she used an existing platform to help finance herself using social media. Informant 3 also agrees that during the period of the MCO, he has been using Facebook in trying to sell food. Informant 8 said she was a little nervous because this is the first time she sold things online but she has been getting encouragement and support from friends. According to Informant 8 , she drew public attention to simply buying her products with social media websites such as Facebook and Instagram.

\section{Online Games as Source of Income}

Informant 10 says, while he enjoys browsing social media during the MCO period, he also realizes that video games can help him generate income as well. This is supported by Khalizan (2019), saying that one student started video streaming of PlayerUnknown's Battlegrounds (PUBG) through the Facebook page. He also said that playing video games is not just a hobby, but can be a source of income because it is able to earn about four figures per month. Therefore, he could pay his tuition fees and take advantage of video games as free stress therapy after a day of learning. This is also expressed by Informant 5 about online games.

According to Informant 5 and 8, online games have been around for some time, but since MCO began, many have played the games actively. Informant 5 said throughout the MCO period, he earned about RM1350 playing only online games.

\section{Access to Free Television Channels}

Various entertainment channels were offered to Malaysians during the MCO period. Informant 1 says that by watching television with her child, she thinks less about her problems, especially during this COVID-19 pandemic. Informant 2 also stated that he had received a great deal of information on the status of COVID-19 in Malaysia by watching TV news. Informant 4 agrees with informant 2 to rely only on news broadcasts on television. 
DEVELOPMENT

Vol. 10, No. 3, 2021, E-ISSN: 2226-6348 @ 2021 HRMARS

Figure 1 below summarizes entertainment media channels usage patterns during the MCO period in Malaysia.

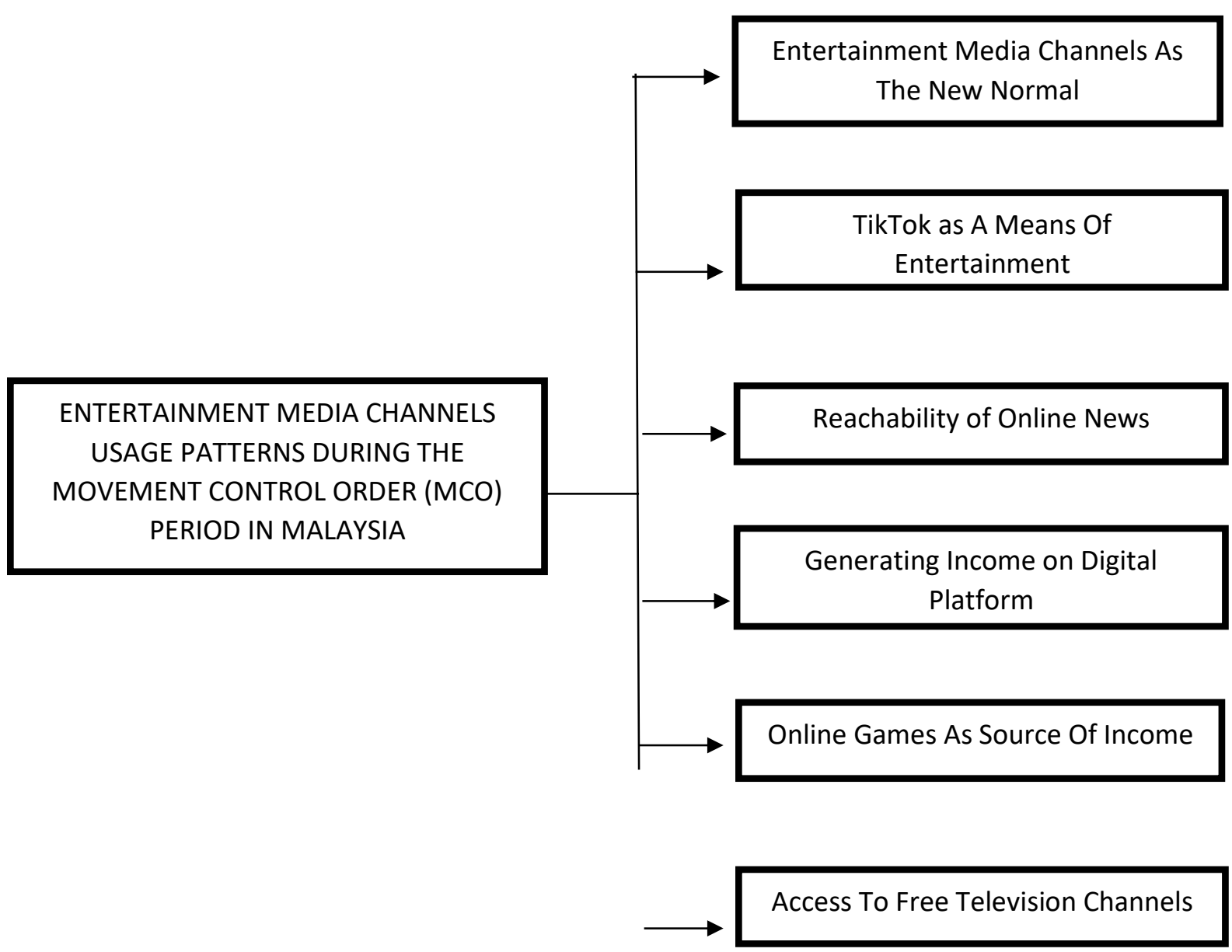

Figure 1: Entertainment Media Channels Usage Patterns During The MCO Period In Malaysia

\section{Conclusion}

To deal with pressure and worries regarding the COVID-19 pandemic, the entertainment media serves as a platform for providing interesting content and options that are of interest to the public. The TikTok app and other media channels such as YouTube, and video games platform have also received great support. Entertainment activities during the period COVID19 is considered crucial. It can be concluded that during MCO, Malaysians uses entertainment media channels as the new normal, as a means of entertainment, to read the news online, play online games and generate income on digital platform and watch free TV channels.

\section{Corresponding Author}

Mohd Syuhaidi Abu Bakar

Universiti Teknologi MARA (UiTM), Shah Alam, Malaysia

Email: syuhaidi@uitm.edu.my

\section{Acknowledgement}

The publication fee for this article is funded by Geran GIP (600-IRMI 5/3/GIP (011/2019)) granted by Universiti Teknologi MARA (UiTM), Malaysia. 


\section{References}

Awani, A. (2020). PKP: Astro tawarkan pelbagai program pendidikan menarik. Retrieved from https://www.astroawani.com/berita-hiburan/pkp-astro-tawarkanpelbagai-program-pendidikan-menarik-237537

Bernama. (2020). Inisiatif \#Muzikdirumah, Hiburan Untuk Peminat Muzik Tempatan Sepanjang PKP. Retrieved from http://www.astroawani.com/berita-hiburan/inisiatifmuzikdirumah-hiburan-untuk-peminat-muzik-tempatan-sepanjang-pkp-237613

Ellias, N. E. (2020). Nyanyi dari rumah- Komitmen unit hiburan TV sepanjang PKP.

Retrieved from http://kopipanas.rtm.gov.my/nyanyi-dari-rumah-komitmen-unithiburan-tv-sepanjang-pkp/.

FMT Reporters. (2020). Putrajaya perkenal program TV pendidikan semasa PKP.

Retrieved from

https://www.freemalaysiatoday.com/category/bahasa/2020/04/04/putrajayaperkenal-program-tv-pendidikan-semasa-pkp/.

Guest, G., Bunce, A., \& Johnson, L. (2006). How many interviews are enough? Field Methods, 18(1), 59-82. doi:10.1177/1525822x05279903.

Hassan, S. M. (2020). Penggunaan Internet naik 9 peratus. Retrieved from https://www.hmetro.com.my/itmetro/2020/04/561142/penggunaan-internet-naik9-peratus.

Hayin, M. N. A. (2020). Mengurus emosi, mental ketika PKP. Retrieved from https://www.msn.com/en-my/news/berita/mengurus-emosi-mental-ketika-pkp/arBB13whtq.

Huda, N. (2020). Inisiatif Astro beri siaran percuma dihargai - kaji selidik. Retrieved From http://www.astroawani.com/berita-malaysia/inisiatif-astro-beri-siaranpercuma-dihargai-kaji-selidik-245285.

Hussain, H. (2020). PKP: Manfaat media sosial untuk kekal positif. Retrieved from https://www.sinarharian.com.my/article/77233/KHAS/Koronavirus/PKP-Manfaatmedia-sosial-untuk-kekal-positif.

Jaafar, N. (2020). Malaysia berdepan isu pengangguran, pendapatan kesan Covid19. Retrieved from https://www.sinarharian.com.my/article/80226/KHAS/Koronavirus/Malaysiaberdepan-isu-pengangguran-pendapatan-kesan-Covid-19.

Khalizan, M. I. M. (2019). Kaki game 'buat duit' dengan PUBG, siap boleh bagi mak ayah. Retrieved from https://www.mstar.com.my/sukan/esport/2019/03/20/pubg-jana-pendapatan.

Lajis, A. S. (2020). YouTuber masakan mula curi hati rakyat Malaysia... Retrieved from https://www.sinarharian.com.my/article/82421/BERITA/Viral/YouTubermasakan-mula-curi-hati-rakyat-Malaysia.

Mohd, W. (2020). Iflix Tayang Filem Baharu Setiap Minggu Secara Percuma.

Retrieved from https://sinarplus.sinarharian.com.my/lifestyle/iflix-tayang-filembaharu-setiap-minggu-secara-percuma/.

Muhammad, A. (2020). Video Tik Tok bos Mydin sekali lagi curi tumpuan. Retrieved from https://www.sinarharian.com.my/article/88998/BERITA/Viral/Video-Tik-Tokbos-Mydin-sekali-lagi-curi-tumpuan.

Nana. (2020). Cara Mudah Tebus Internet Percuma, Semua Telco Di Malaysia 
Sepanjang PKP. Retrieved from https://www.remaja.my/cara-mudah-tebus-internetpercuma-semua-telco-di-malaysia-sepanjang-pkp/.

Parzi, N. M., \& Ruzki, M. R. (2020). COVID-19: Masalah emosi isu utama kesihatan mental rakyat. Retrieved from https://www.bharian.com.my/berita/nasional/2020/05/690727/covid-19-masalahemosi-isu-utama-kesihatan-mental-rakyat.

Salleh, M. M. A., \& Ilham, M. N. M. (2017). Pengalaman dan kesedaran pengguna dewasa terhadap isu pengawasan di media sosial. Malaysian Journal of Communication, 33(1), 502-512. Retrieved from https://ejournal.ukm.my/mjc/article/view/17010/7723.

Sallehuddin, M. S. (2020, March 22). COVID-19: Stesen TV MPB siar maklumat terkini. Retrieved from https://www.bharian.com.my/hiburan/lainlain/2020/03/667821/covid-19-stesen-tv-mpb-siar-maklumat-terkini.

Sualman, I. (2019). Malaysia obses media sosial. Retrieved from https://www.sinarharian.com.my/article/27675/KOLUMNIS/Malaysia-obses-mediasosial.

Tee, J. P. (2020). Buat yang terbaik semasa PKP untuk menjana pendapatan. Retrieved from https://www.utusanborneo.com.my/2020/04/16/buat-yang-terbaiksemasa-pkp-untuk-menjana-pendapatan. 